\title{
GLUCOSE TOLERANCE IN THE NEONATAL PERIOD AND DURING THE FIRST SIX MONTHS OF LIFE
}

\author{
BY \\ ULLA VON EULER, YNGVE LARSSON, and BENGT PERSSON \\ From the Department of Pediatrics, Karolinska Institutet, Crown \\ Princess Lovisa's Children's Hospital, Stockholm, Sweden
}

(RECEIVED FOR PUBLICATION DECEMBER 23, 1963)

It is well established that the average blood sugar level of normal and healthy full-term and premature infants is lower than in older children, although the individual variations in, and range of the level during, the neonatal period are considerable (Baens, Lundeen and Cornblath, 1963; Farquhar, 1954; Pedersen, 1952; Smith, 1959; Wolf, 1960; Zetterström, 1961, among others). In addition the glucose tolerance, measured by oral or intravenous tests, seems to be lower in normal newborn infants than in older children and adults (Baird and Farquhar, 1962; Bowie, Mulligan and Schwartz, 1963; Stegmann and Beck, 1955). These observations do not fully agree with the conception that the normal term or premature infant has essentially normal (if perhaps a little slow or imprecise) regulatory mechanisms for carbohydrate metabolism' (Smith, 1959). It was, therefore, the purpose of the present study to reinvestigate glucose tolerance during the newborn period and in older infants and children in order to establish at what age the possibly low tolerance of the newborn reaches the adult level.

\section{Material and Methods}

The material consists of 142 healthy children, divided into five age-groups (A-E) as shown in Table 1. Thus 98 infants delivered per vaginam were studied at various times during the neonatal period, 17 infants 1-6 months old (mean age $2 \cdot 6$ months), and 27 children $5-15$ years old. Data regarding the last group have been published previously (von Euler and Larsson, 1962). For comparison with the normal infants, glucose tolerance was also studied in 6 premature newborns, 8 newborn infants of diabetic mothers, and 6 cases of haemolytic disease of the newborn due to $R \mathbf{h}$ incompatibility.

Glucose tolerance was measured with an intravenous tolerance test in which glucose was given by percutaneous puncture of an antecubital vein in the infants, with the aid of a scalp vein infusion set. A $25^{\circ}$ solution of glucose was used: infants were given $10 \mathrm{ml}$., older children $0.5 \mathrm{~g}$./ kg. body weight, and the injection was performed within two to four minutes. Blood sugar was determined according to Hultman (1959) before and every 10 minutes of the first hour after the injection. The disappearance rate of glucose from the blood was calculated according to the method of Hamilton and Stein (1942) as modified by Ikkos and Luft (1957), and expressed as the constant

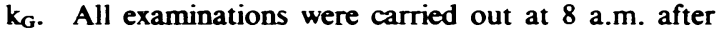
8-12 hours' fasting. No side-effects were observed.

\section{Results}

The mean fasting blood sugar levels of the healthy children in the age-groups A-E are given in Table 1. They were lowest during the first four days of life, but thereafter reached the same average levels as in infants 1-6 months old and in older children. Statistical comparison ( $t$ test) between the mean value $(65 \cdot 1 \mathrm{mg}$. $/ 100 \mathrm{ml}$.) of the 67 infants observed from the age of 1 hour to 4 days and that $(81 \cdot 6 \mathrm{mg}$.) $100 \mathrm{ml}$.) of the 31 infants aged 4 to 8 days showed a highly significant difference ( $p<0 \cdot 001$ ).

In the premature infants, the children of diabetic mothers, and the cases of $\mathrm{Rh}$ incompatibility, the mean fasting blood sugar levels were lower than those of normal children of the same ages (Table 3 ). The differences were significant for the premature infants $(p<0.01)$ and the children of diabetic mothers $(p<0.01)$, but only probably significant for the $R h$ cases $(p<0 \cdot 02)$.

The glucose tolerance of the healthy children is demonstrated in Table 2 and Fig. 1. The mean value of $k_{G}$ was low during the first four hours of life, increased slowly during the following 24 hours, but remained low throughout the neonatal period. A much higher tolerance was found, however, in the older infants (group D), in which it was even higher than in the children 5-15 years old (group E), whose mean $k_{G}$ value was on the same level as in adults (von Euler and Larsson, 1962). Statistical comparisons ( $t$ tests) between the mean values of the different age-groups gave the following results. 
TABLE 1

FASTING BLOOD SUGAR LEVELS OF HEALTHY CHILDREN IN DIFFERENT AGE-GROUPS

\begin{tabular}{|c|c|c|c|c|c|}
\hline \multirow{2}{*}{ Groups } & \multirow{2}{*}{ Age } & \multirow{2}{*}{ No. of Cases } & \multicolumn{3}{|c|}{ Fasting blood sugar (mg./100 ml.) } \\
\hline & & & Mean Values & Rar & \\
\hline $\mathbf{A}$ & $1-4 \mathrm{hr}$ & 11 & $58 \cdot 6$ & 41-92 & \\
\hline B & $6-24 \mathrm{hr}$. & 20 & $74 \cdot 1$ & $46-115$ & \\
\hline $\mathrm{C}$ & $\begin{array}{l}\text { 1-2 days } \\
2-3 \text { days } \\
3-4 \text { days } \\
4-5 \text { days } \\
5-6 \text { days } \\
6-8 \text { days }\end{array}$ & $\begin{array}{l}\left.\begin{array}{l}10 \\
11 \\
15 \\
12 \\
10 \\
9\end{array}\right\} 36 \\
31\end{array}$ & $\left.\begin{array}{l}60 \cdot 8 \\
57 \cdot 6 \\
66 \cdot 4 \\
81 \cdot 3 \\
81 \cdot 0 \\
82 \cdot 8\end{array}\right\} 82 \cdot 1$ & $\begin{array}{l}49-95 \\
37-75 \\
46-82 \\
59-97 \\
59-101 \\
60-103\end{array}$ & $\begin{array}{l}37-95 \\
59-103\end{array}$ \\
\hline $\mathbf{D}$ & $1-6 \mathrm{mth}$. & 17 & $86 \cdot 3$ & $70-98$ & \\
\hline $\mathrm{E}$ & 5-15 yr. & 27 & $83 \cdot 3$ & $71-109$ & \\
\hline
\end{tabular}

Between groups A and B no significant difference; between $B$ and $C$, highly significant difference $(\mathrm{p}<0.001)$; between $\mathrm{C}$ and $\mathrm{D}$, highly significant difference $(p<0.001)$; between $D$ and $E$, significant difference $(\mathrm{p}<0.01)$, and between $\mathrm{C}$ and $\mathrm{E}$, highly significant difference $(p<0.001)$. Comparison between the mean $\mathrm{k}_{\mathrm{G}}$ values of the 36 children aged 1 to 4 days and the 31 children aged 4 to 8 days within group $\mathrm{C}$ showed no significant difference in contrast to the corresponding fasting blood sugar values in the same group of infants.

The average glucose tolerance of the children of diabetic mothers was significantly higher $(p<0.01)$ than that of normal infants of the same ages (Table 3). The tolerance of the premature children and the $\mathrm{Rh}$ cases did not differ significantly from that of the normal group.

TABLE 2

GLUCOSE TOLERANCE OF HEALTHY CHILDREN IN DIFFERENT AGE-GROUPS, EXPRESSED AS THE DISAPPEARANCE RATE OF GLUCOSE $(\mathrm{k})$ IN THE INTRAVENOUS GLUCOSE TOLERANCE TEST

\begin{tabular}{|c|c|c|c|c|c|c|c|}
\hline Groups & Age & $\begin{array}{l}\text { No. of } \\
\text { Cases }\end{array}$ & $\bar{x}$ & $e(\bar{x})$ & $\mathbf{k}_{\mathrm{a}}$ & S.D. & Range \\
\hline $\mathrm{A}$ & $1-4 \mathrm{hr}$. & 11 & 0.78 & $0 \cdot 11$ & & 0.35 & $0.5-1.6$ \\
\hline B & 6-24 hr. & 20 & 0.88 & 0.09 & & 0.39 & $0 \cdot 5-1 \cdot 9$ \\
\hline $\mathrm{C}$ & $\left\{\begin{array}{l}1-2 \text { days } \\
2-3 \text { days } \\
3-4 \text { days } \\
4-5 \text { days } \\
5-6 \text { days } \\
6-8 \text { days } \\
1-8 \text { days }\end{array}\right.$ & $\begin{array}{r}10 \\
11 \\
15 \\
12 \\
10 \\
9 \\
67\end{array}$ & $\begin{array}{l}1 \cdot 18 \\
1 \cdot 12 \\
1 \cdot 24 \\
1 \cdot 21 \\
1 \cdot 33 \\
1 \cdot 16 \\
1 \cdot 21\end{array}$ & 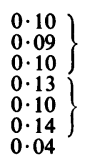 & $\begin{array}{l}1 \cdot 19 \pm 0.06 \\
1.23 \pm 0.07\end{array}$ & $\begin{array}{l}0.33 \\
0.31 \\
0.40 \\
0.45 \\
0.30 \\
0.42 \\
0.37\end{array}$ & $\begin{array}{l}0 \cdot 7-1 \cdot 7 \\
0 \cdot 8-1 \cdot 7 \\
0 \cdot 7-2 \cdot 2 \\
0 \cdot 5-1 \cdot 8 \\
0 \cdot 7-1 \cdot 8 \\
0 \cdot 5-2 \cdot 0 \\
0 \cdot 5-2 \cdot 2\end{array}$ \\
\hline D & 1-6 mth. & 17 & 2.09 & 0.15 & & 0.62 & $1 \cdot 1-3 \cdot 5$ \\
\hline $\mathbf{E}$ & 5-15 yr. & 27 & $1 \cdot 65$ & 0.08 & & $0 \cdot 40$ & $0 \cdot 9-2 \cdot 8$ \\
\hline
\end{tabular}

$\bar{x}$ mean value; $e(\bar{x})$ error of the mean; S.D. standard deviation.

TABLE 3

GLUCOSE TOLERANCE (ka) AND FASTING BLOOD SUGAR IN PREMATURE INFANTS, CHILDREN OF DIABETIC MOTHERS AND NEWBORNS WITH HEMOLYTIC DISEASE DUE TO RH-INCOMPATIBILITY

\begin{tabular}{|c|c|c|c|c|c|c|}
\hline \multirow{2}{*}{ Groups } & \multirow{2}{*}{$\begin{array}{l}\text { No. of } \\
\text { Cases }\end{array}$} & \multirow{2}{*}{$\begin{array}{c}\text { Age } \\
\text { (hr.) }\end{array}$} & \multicolumn{2}{|c|}{$\mathrm{k}_{\mathrm{G}}$} & \multicolumn{2}{|c|}{ Fasting Blood Sugar (mg./100 ml.) } \\
\hline & & & Mean Values & Range & Mean Values & Range \\
\hline Premature children & 6 & 3-96 & $1 \cdot 20$ & $0 \cdot 5-2 \cdot 5$ & $45 \cdot 2$ & $23-76$ \\
\hline Children of diabetic mothers & 8 & $5-63$ & $1 \cdot 46$ & $0 \cdot 7-2 \cdot 3$ & $44 \cdot 9$ & $28-79$ \\
\hline Cases of $\mathrm{Rh}$-incompatibility & 6 & $12-20$ & $1 \cdot 08$ & $0 \cdot 7-1 \cdot 7$ & $50 \cdot 8$ & $18-76$ \\
\hline
\end{tabular}




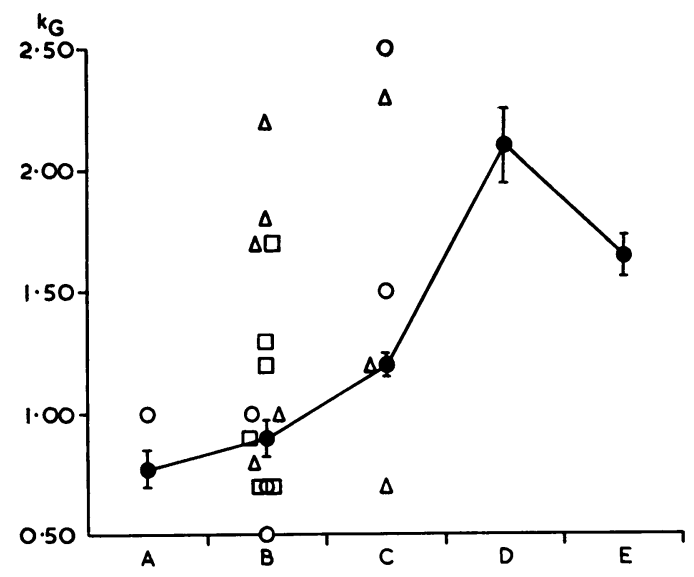

FIG. 1.-Glucose tolerance $\left(k_{G}\right)$ in different age-groups A-E (see text) (mean values \pm errors of the mean). For comparison the individual values for a few additional infants: $O$ premature children; $\triangle$ children of diabetic mothers; $\square$ children with Rh incompatibility.

\section{Discussion}

The cause of the low fasting blood sugar level in the newborn infant has been repeatedly discussed, but remains unknown. A low glucose output from the liver does not seem probable as no defect in the hepatic enzymes involved in glycogenolysis has been demonstrated (Zetterström, 1961). Though Cornblath, Ganzon, Nicolopoulos, Baens, Hollander, Gordon and Gordon (1961) and Mulligan and Schwartz (1962) showed that the response of newborn infants to glucagon and epinephrine was diminished, the hyperglycaemia after glucagon was prolonged, and their studies did not suggest inadequate glycogen stores in the liver nor immaturity in the enzymes necessary for glucose release from the liver. Further, in connexion with insulin-induced hypoglycaemia, the urinary output of catecholamines increases in the same way as in older children (Greenberg, Lind and von Euler, 1960). The high glucose-6-phosphatase activity in the liver of newborns (Dawkins, 1961) and the rapid decrease of the glycogen content of the liver also speak in favour of a normal or even accelerated hepatic glucose output in the newborn infant. Nor can the fasting hypoglycaemia of the newborn be explained by hyperinsulinism, as newborn infants have a low insulin-like activity in their blood plasma (Baird and Farquhar, 1962; Stimmler, Brazie and O'Brien, 1963). The most probable explanation seems to be a high uptake of glucose in the tissues that are independent of insulin action for the transfer of glucose from the extra- to the intracellular space, i.e. above all the central nervous system.
Glucose tolerance has previously been studied in the neonatal period by Baird and Farquhar (1962), Bowie et al. (1963), Desmond (1953), and Stegmann and Beck (1955), According to Desmond (1953), the response of premature and full-term infants to intravenously given glucose is within normal adult limits. However, this conclusion was based on the general appearance of the blood sugar curves in the tolerance test, without use of the more exact method of calculating the disappearance rate of glucose. Stegmann and Beck (1955), using a two-dose oral glucose test, found that the Staub-Traugott effect was absent during the first day of life, but that when the test was repeated in the second week, a normalization had occurred in 14 of the 20 infants studied. Double tolerance tests were also made by Bowie et al. (1963), using the intravenous technique with approximately two hours between the injections. The $k_{G}$ value increased significantly from 0.90 after the first glucose load to $2 \cdot 16$ after the second. Similarly, they found that when infants were given intravenous tolerance tests on the first as well as on the third day of life, the $\mathrm{k}_{\mathrm{G}}$ values were significantly higher on the last occasion than in infants who were only tested on the third day. This improvement in glucose tolerance may be due to stimulation of insulin activity either by increased release from the $\beta$ cells, caused by the first glucose administration, or by dissociation of postulated circulating insulin complexes (Antoniades, Gundersen, Beigelman, Pyle and Bougas, 1962). In children of diabetic mothers similar mechanisms seem to be present. These infants have a high glucose tolerance as shown by Baird and Farquhar (1962) and confirmed in this study, and also a much higher insulin-like activity in the blood plasma after glucose injection than normal newborns. This hyperinsulinism corresponds to the hyperplasia of the pancreatic islets in these infants, and is probably the result of a prenatal islet stimulation caused by maternal hyperglycaemia.

Islet hyperplasia has also been found in some cases of erythroblastosis (Warren and LeCompte, 1952): this was the reason why such cases were included in this study. As their glucose tolerance did not differ from that of the normal newborn infants, it is likely that islet hyperplasia in cases of $\mathrm{Rh}$ incompatibility is caused by another factor than in the infants of diabetic mothers, and that there is no hyperinsulinism in such cases.

Our results indicate that under normal conditions glucose tolerance is very low during the first day of life, that it increases slowly during the following week, but that it remains low throughout the neonatal period in contrast to the more rapid increase of the fasting blood sugar level. On the other hand 
glucose tolerance was much higher in the infants 1-6 months old, an even higher tolerance than in older children and adults (Loeb and Conard, 1961). The low tolerance of the newly born may be caused by hyperadrenocorticism, as the newborn infant has a comparatively large adrenal gland and a higher level of corticosteroids in the plasma than at a later age. In addition, the rate of cortisol production is on the same level as in adults (Kenny, Malvaux and Migeon, 1963) and the capacity for glucuronide conjugation of the steroid is reduced (Migeon, 1961).

Another perhaps more natural explanation is the physiological state of starvation of the newborn infant, who loses weight and consumes stores of fat for metabolic needs (Smith, 1959; Widdowson, 1961). Analogous circumstances of starvation and katabolism cause hypoinsulinism and lower glucose tolerance in older subjects as well. A few months after the neonatal period the situation is completely different: the infant is then in an anabolic phase of growth, gets an abundant supply of calories, and increases rapidly in weight. This may explain the high glucose tolerance found in infants of 1 to 6 months. We feel justified in postulating that this high tolerance is caused by a relative hyperinsulinism, which thus is physiological in this period of the infant's life.

\section{Summary}

Glucose tolerance was studied in 142 healthy children divided into different age-groups. The results confirmed the presence of a low fasting blood sugar level in the newborn children. It is probably due to a high uptake of glucose in insulin-independent tissues, above all the central nervous system. The glucose tolerance expressed as the disappearance rate of intravenously injected glucose $\left(k_{\mathrm{G}}\right)$ was low during the first hours of life $\left(k_{G}=0 \cdot 78\right)$, increased a little during the following 24 hours $\left(k_{G}=0 \cdot 88\right)$, but remained low throughout the first eight days of life $\left(\mathrm{k}_{\mathrm{G}}=1 \cdot 21\right)$.

In contrast, children aged 1-6 months had a significantly higher tolerance $\left(k_{G}=2 \cdot 09\right)$ even when compared with a group of 5 to 15-year-old children $\left(\mathrm{k}_{\mathrm{G}}=1 \cdot 65\right)$.

Possible causes of the low tolerance in the neonatal period are discussed and include hyperadrenocorticism and hypoinsulinism in the physiological state of starvation of the newborn infant. In contrast, the high tolerance in the infant of 1 to 6 months is explained by an adaptation to a relative hyperinsulinism in the extreme anabolic phase of growth during infancy.

We wish to thank Dr. Verner Westberg for his kind permission to study the newborn infants at the maternity department of St. Erik's Hospital.
We are also greatly indebted to Mrs. Margareta Helander and Mrs. Berit Tutturen for valuable assistance throughout the study.

The investigation was made possible by grants from Nordisk Insulinfond and Karolinska Institutet.

\section{REFERENCES}

Antoniades, H. N., Gundersen, K., Beigelman, P. M., Pyle, H. M. and Bougas, J. A. (1962). Studies on the state, transport and regulation of insulin in human blood. Diabetes, 11, 261.

Baens, G. S., Lundeen, E. and Cornblath, M. (1963). Studies of carbohydrate metabolism in the newborn infant, VI Levels of glucose in blood in premature infants. Pediatrics, 31, 580.

Baird, J. D. and Farquhar, J. W. (1962). Insulin-secreting capacity in newborn infants of normal and diabetic women. Lancet, 1,71 .

Bowie, M. D., Mulligan, P. B. and Schwartz, R. (1963). Intravenous glucose tolerance in the normal newborn infant: The effects of a double dose of glucose and insulin. Pediatrics, 31, 590.

Cornblath, M., Ganzon, A. F., Nicolopoulos, D., Baens, G. S., Hollander, R. J., Gordon, M. H. and Gordon, H. H. (1961). Studies of carbohydrate metabolism in the newborn infant. III. Some factors influencing the capillary blood sugar and the response to glucagon during the first hours of life. ibid., 27, 378.

Dawkins, M. J. R. (1961). Discussion on carbohydrate metabolism and role of the liver. In Ciba Foundation Symposium on Somatic Stability in the Newly Born, ed. G. E. W. Wolstenholme and M. O'Connor, p. 70. Churchill, London.

Desmond, M. M. (1953). Observations related to neonatal hypoglycemia. J. Pediat., 43, 253.

von Euler, U. and Larsson, Y. (1962). Glucose tolerance tests in children. Scand. J. clin. Lab. Invest., 14, Suppl. 64, p. 62.

Farquhar, J. W. (1954). Control of the blood sugar level in the neonatal period. Arch. Dis. Childh., 29, 519.

Greenberg, R. E., Lind, J. and von Euler, U. S. (1960). Effect of posture and insulin hypoglycemia on catecholamine excretion in the newborn. Acta paediat. (Uppsala), 49, 780.

Hamilton, B. and Stein, A. F. (1942). The measurement of intravenous blood sugar curves. J. Lab. clin. Med., 27, 491.

Hultman, E. (1959). Rapid specific method for determination of aldosaccharides in body fluids. Nature (Lond.), 183, 108.

Ikkos, D. and Luft, R. (1957). On the intravenous glucose tolerance test. Acta endocr. (Kbh.), 25, 312.

Kenny, F. M., Malvaux, P. and Migeon, C. J. (1963). Cortisol production in newborn babies, older infants, and children. Pediatrics, 31, 360.

Loeb, H. and Conard, V. (1961). Étude de la tolérance glucidique chez l'enfant. Présentation des résultats observés entre six et quinze. Rev. franc. Étud. clin. biol., 6, 609.

Migeon, C. J. (1961). The endocrine function of the newborn. In Ciba Foundation Symposium on Somatic Stability in the Newly Born, ed. G. E. W. Wolstenholme and M. O'Connor, p. 215. Churchill, London.

Mulligan, P. B. and Schwartz, R. (1962). Hepatic carbohydrate metabolism in the genesis of neonatal hypoglycemia. Pediatrics, $30,125$.

Pedersen, J. (1952). Diabetes and Pregnancy. Blood Sugar of Newborn Infants. Danish Science Press, Copenhagen.

Smith, C. A. (1959). The Physiology of the Newborn Infant, 3rd ed. Blackwell, Oxford.

Stegmann, H. and Beck, H. (1955). Die doppelte Traubenzuckerbelastung nach Staub-Traugott beim Neugeborenen. Ärztl. Forsch. (Grig), 9, 406.

Stimmler, L., Brazie, J. and O'Brien, D. (1963). Serum insulin levels in the normal newborn infant. J. Pediat., 63, 733.

Warren, S. and LeCompte, P. M. (1952). The Pathology of Diabetes Mellitus, 3rd ed. Lea and Febiger, Philadelphia.

Widdowson, E. M. (1961). Metabolic effects of fasting and food. In Ciba Foundation Symposium on Somatic Stability in the Newly Born, ed. G. E. W. Wolstenholme and M. O'Connor, p. 39. Churchill, London.

Wolf, H. (1960). Blutzucker bei Neugeborenen. Klin. Wschr., 38, 87.

Zetterström, R. (1961). Carbohydrate metabolism and the rôle of the liver. In Ciba Foundation Symposium on Somatic Stability in the Newly Born, ed. G. E. W. Wolstenholme and M. O'Connor, p. 59. Churchill, London. 